\title{
Expression and Functional Analysis of a Transgenic Cytochrome P450 Monooxygenase in Pueraria mirifica
}

(Analisis Ekspresi dan Fungsian Transgen Sitokrom P450 Monooksigenase dalam Pueraria mirifica)

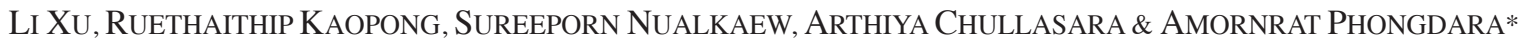

\begin{abstract}
Isoflavonoids are the main compound in White Kwao Krua (Pueraria mirifica), which is an effective folk medicinal plant endemic to Thailand. It has been widely used for improving human physical and treating diseases. There are substances with estrogenic activities have been isolated from P. mirifica, such as puerarin, daidzein and genistein. Isoflavone synthase (IFS) is one of the key enzymes in Leguminous plants to convert liquiritigenin, liquiritigenin C-glucoside and naringenin chalcone to isoflavonoids. The aim of this research was to enhance the production of isoflavonoids by metabolic engineering. Transgenic plants were constructed by introducing P450 gene ( $\mathrm{Eg} P 450)$ which is similar to IFS from oil palm (Elaeis guineensis), into P. mirifica by a biolistic method. After the transgenic plants had proved successfully, isoflavonoids of each group plants were determined by HPLC. The contents of daidzein and genistein in transgenic plants were higher than the control plants.
\end{abstract}

Keywords: Elaeis guineensis; isoflavonoids; Pueraria mirifica; P450 gene; transgenic plants

ABSTRAK

Isoflavonoid adalah sebatian utama dalam White Kwao Krua (Pueraria mirifica) yang merupakan tumbuhan perubatan yang berkesan dan endemik di Thailand. Ia telah digunakan secara meluas untuk meningkatkan tahap fizikal manusia dan merawat penyakit. Terdapat bahan dengan aktiviti estrogen yang telah dipencil daripada P. Mirifica seperti puerarin, daidzein dan genistein. Sintas isoflavon (IFS) merupakan salah satu enzim penting dalam tumbuhan kekacang yang menukar likuiritigenin, likuiritigenin C-glukosid dan naringenin kalkon kepada isoflavonoid. Kajian ini bertujuan meningkatkan pengeluaran isoflavonoid melalui kejuruteraan metabolisma. Tumbuhan transgen telah dihasilkan dengan memperkenalkan gen P450 (EgP450) yang menyerupai IFS daripada kelapa sawit (Elaeis guineensis) kepada P. mirifica melalui kaedah biolistik. Selepas tumbuhan transgen terbukti berjaya, isoflavonoid setiap kumpulan tumbuhan telah ditentukan melalui HPLC. Kandungan daidzein dan genistein dalam tumbuhan transgen adalah lebih tinggi daripada tumbuhan kawalan.

Kata kunci: Elaeis guineensis; gen P450; isoflavonoid; Pueraria mirifica; tumbuhan transgen

\section{INTRODUCTION}

Pueraria mirifica has a long using history in folk medicine in Thailand. This plant grows in the wild in northern, northeastern and western of Thailand (Cherdshewasart et al. 2007a). It belongs to Leguminosae family, locally called different names, but of which white Kwao Krua is more popular (Lakshnakara et al. 1952). P. mirifica has been claimed to improve the human physical appearances such as re-growing hair, promoting black hair, enhance the flexibility of the body and sexual performance, recovering smooth skin and prolonging life. In recent years, P. mirifica has been included into cosmetic, dietary supplement and pharmaceutical products (Malaivijitnond 2012).

More than 20 chemical substances with estrogenic activities, mainly isoflavones, have been isolated from $P$. mirifica, such as puerarin, daidzein, genistein, kwakhurin, tuberosin, and mirificin (Malaivijitnond 2012). Isoflavonoids, a class of flavonoid phenolic compounds, are particularly prevalent in Leguminosae (Dixon \&
Sumner 2003). By now, puerarin (Urasopon et al. 2008), miroestrol (Yusakul et al. 2011) and kwakhurin (Ingham et al. 2002; Ito et al. 2005) are found only in P. mirifica. The isoflavonoids of $P$. mirifica depended on genotype (Cherdshewasart \& Sriwatcharakul 2007), environmental effect and plant age, but they are almost less than $0.2 \%$ of isoflavonoids contents (Cherdshewasart et al. 2007b; Malaivijitnond et al. 2004; Urasopon et al. 2008).

In Pueraria, the whole processes of isoflavonoids biosynthesis include two main stages (Dhaubhadel 2011; Franzmayr et al. 2012; He et al. 2011). The first stage is the biosynthesis of the common precursor of isoflavonoid, the 4-coumaroyl-CoA, which is synthesized orderly from phenylalanine by phenylalanine ammonia-lyase (PAL), cinnamic acid 4-hydroxylase $(\mathrm{C} 4 \mathrm{H})$ and 4-coumarate: CoA ligase (4CL). The biosynthesis genistein, daidzein, puerarin and other isoflavonoids from 4-coumaroyl$\mathrm{CoA}$ and aroyl-CoA is the second stage. The naringenin chalcone synthesized from 4-coumaroyl-CoA and 
aroyl-CoA by chalcone synthase (CHS), which form a naringenin by chalcone isomerase ( $\mathrm{CHI})$. The latter could then converted to genistein by isoflavone synthase (IFS). The isoliquiritigenin is synthesized from 4-coumaroylCoA and aroyl-CoA by CHS and CHR, which form a liquirtigenin by CHI. The latter could then be converted to daidzein by the sequential actions of IFS and UDPglucosyl transferase (UGT). Puerarin could be synthesized directly from daidzein by chalcone glycosyltransferase (GT). Furthermore, the biosynthesis of puerarin has other two pathways. One is isoliquiritigenin could be glycosylated by GT to form a chalcone C-glucoside and then isomerized to liquirtigenin C-glucoside by CHI. Liquirtigenin $\mathrm{C}$-glucoside could be converted to puerarin by IFS and trihydroxyflavanone C-glucoside dehydratase (HID). The other is the puerarin could be synthesize from trihydroxyflavanone by GT and HID.

In the process of isoflavonoids biosynthesis, isoflavone synthase (ISF) is one of the key enzymes, which belongs to Cytochrome $\mathrm{P} 450$ protein family, converts liquiritigenin, naringenin and liquiritigenin $\mathrm{C}$-glucoside to daidzein, genistein and trihydroxyflavanone C-glucoside, respectively (Hashim et al. 1990; Sawada et al. 2002).

Cytochrome P450 monooxygenases (CYPs, P450) are ubiquitous enzymes from many species. P450 enzymes of higher plants were shown to catalyze the metabolism of isoflavoniods specifically. Expression of soybean IFS in anthocyanin accumulating tobacco tissues resulted in enhanced levels of isoflavonoids production (Tian \& Dixon 2006; Yu et al. 2000). Other studies showed that the P450 enzymes can metabolize exogenous chemicals such as herbicides (Bolwell et al. 1994; Schuler 1996).

In this research, we aimed to enhance the production of isoflavonoids in P. mirifica by using gene transformation. P450 gene (EgP450) isolated from oil palm (Phongdara et al. 2012) is chosen as a target gene to transfer into $P$. mirifica. EgP450 is predicted to be an enzyme which acts as isoflavonoids synthase. The modified P. mirifica, is expected to produce a high yield of secondary metabolites.

\section{MATERIALS AND METHODS}

\section{PLANT MATERIALS}

The seeds of P. mirifica plants were brought from Lampang province of Thailand. They were used for in vitro plant cultures to obtain transgenetic plants. The P. mirifica plants were discriminated and identified by its DNA barcodes.

IDENTIFYING P. MIRIFICA SPECIES DNA EXTRACTION, AMPLIFICATION AND SEQUENCING

Leaf tissues of $P$. mirifica dried in silica gel. Total DNA was extracted using the plant genomic DNA Mini Kit (Gene aid, New Taipei, Taiwan). Four DNA barcodes (ITS region, $r b c L$, $m a t K$, and $p s b A-t r n H$ ) amplified by the polymerase chain reaction (PCR) technique. The total volume of reaction for $25 \mu \mathrm{L}$ consisted of $2 \mu \mathrm{L}(\sim 60 \mathrm{ng})$ DNA, $1 \mu \mathrm{L}$ of $50 \mathrm{mM}$ $\mathrm{MgCl}_{2}, 2.5 \mu \mathrm{L}$ of $10 \times$ PCR buffer, $0.2 \mu \mathrm{L}$ of $5 \mathrm{U} / \mu \mathrm{L}$ Pfu Taq DNA polymerase, $0.5 \mu \mathrm{L} \mathrm{L}$ of $10 \mathrm{mM}$ dNTPs mix, $1.0 \mu \mathrm{L}$ $2.5 \mu \mathrm{M}$ of primers), $17.8 \mu \mathrm{L}$ deionized water. PCR products were first examined by $1.5 \%$ agarose gel electrophoresis and purified using the QIAquick ${ }^{\circledR}$ PCR Purification Kit (Qiagen, Hilden, Germany) and then sequenced in both directions with the primers used for PCR amplification on a sequencer ABI 310 (Applied Biosystems, USA). The sequences submitted to GenBank (supplement Table 1).

\section{SEQUENCING AND BIOINFORMATICS ANALYSIS}

DNA sequences alignments were performed using ClustalX2 and displayed using GeneDOC software (Larkin et al. 2007). The evolutionary relationships of taxa were inferred using the UPGMA method (Sneath \& Sokal 1973), to construct phylogenetic trees by bootstrap analysis from 1000 replications of the data (Felsenstein 1985). The trees are drawn to scale, with branch lengths in the same units as those of the evolutionary distances used to infer the phylogenetic tree. The evolutionary distances were computed using the maximum composite likelihood method. All positions containing gaps and missing data were eliminated. Positions in the final dataset of evolutionary analyses were conducted in MEGA6 (Tamura et al. 2013). The divergence between sequences was analyzed and the number of base substitutions per site from between sequences was calculated. Analyses were conducted using the maximum composite likelihood model (Tamura et al. 2004).

SUPPLEMENT TABLE 1 . Sequences of the Primers for amplification

\begin{tabular}{ll}
\hline Primer name & Sequences $\left(5^{\prime} \rightarrow 3^{\prime}\right)$ \\
\hline rbcL-F & ATGTCACCACAAACAGAGACTAAAGC \\
rbcL-R & TCGCATGTACCTGCAGTAGC \\
matK-F & CGTACAGTACTTTTGTGTTTACGAG \\
matK-R & ACCCAGTCCATCTGGAAATCTTGGTTC \\
PsbA- trnH-F & GTTATGCATGAACGTAATGCTC \\
PsbA- trnH-R & CGCGCATGGTGGATTCACAATCC \\
ITS region -F & TCCTCCGCTTATTGATATGC \\
ITS region -R & GGAAGTAAAAGTCGTAACAAGG \\
18 S-F & CAAAGCAAGCCTACGCTCTG \\
18 S-R & CGTTCTTAGTTGGTGGAGCG \\
GFP1303-F & TCAGTGGAGAGGGTGAAGGTGATG \\
GFP1303-R & CGTTGTGGGAGTTGTAGTTGTATTC \\
EgP450-F & ATGTCTCCCTCCTTGCAACTTC \\
$E g$ P450-R & GCACCATACGGTGAGCACTG \\
\hline
\end{tabular}

\section{PRODUCTION OF TRANSGENIC PLANTS CULTIVATE PLANTS FOR TRANSFORMATION}

The seeds of $P$. mirifica were cultivated in three flowerpots containing soil. Each flowerpot has nine plant seedings which were treated in transformation while the spouts grow at $3-5 \mathrm{~cm}$. 
PREPARATION OF RECOMBINANT EGP450 AND TRANSGENIC PLANTS

The full-length cDNA of P450 enzyme from E. guineensis (EgP450, Genebank: ADM88550.1) was sub-cloned into pCAMBIA vector. Then, the particular primer set corresponding to the beginning of the ORF with the addition of an upstream in-frame are used to amplify EgP450 by PCR machine. The PCR products are ligated to a similarly digested pCAMBIA 1303 (CAMBIA, Australia), carrying the reporter gene (gus-gfp) controlled by a Cauliflower Mosaic Virus (CaMV35S) promoter. The inserted plasmid DNA was sequenced using the 3730 DNA sequencer to ensure the authenticity of the cloned nucleotide sequence (Supplement Figure 1).

The seedling, approximately $3-5 \mathrm{~cm}$ in size, were selected from the same seedling line and bombarded using the PDS-1000/He particle delivery system (BioRad, USA), the conditions for biolistic-mediated gene transfer for P. mirifica were optimized previously (Nakkaew et al. 2010) and the pressure of 1100 psi was chosen for bombardment transformation. Distance between stopping screen and target shelf was $90 \mathrm{~mm}$ and the vacuum was $27 \mathrm{mmHg}$. Gold particle size was $1.0 \mu \mathrm{m}$. Bombardments without DNA and with an empty vector were used as experimental control (Nakkaew et al. 2010).

\section{IDENTIFICATION OF THE RESULT OF TRANSFORMATION}

The expressions of the GFP gene in putative transgenic seedling were visualized using an Olympus BX51 compound microscope and a DP-71 digital camera fitted with a fluorescence unit cubes.

Genomic DNA from putative transgenic plants were isolated followed the user's manual of DNA extraction kits. The amplification was performed in GeneAmp PCR System 2720 (Perkin-Elmer, USA). The CaMV35S promoter primer and $E g \mathrm{P} 450 \mathrm{R}$ SpeI were used in the amplification to confirm the insertion of recombinant EgP450 into the genome of the seedling. Thus GFP primers set will be used as a control to ensure a complete of transgenic $P$. mirifica.

\section{ISOFLAVONOIDS PRODUCTS ANALYSIS VIA HPLC}

Puerarin, genistein and daidzein of the 3 groups of isoflavonoids product were determined by highperformance liquid chromatography (HPLC) (Agilent 1200, America) from transgenic plants. It was performed using Hypersil BDS C18 column, mobile phase including methanol and water by gradient elution (Flow rate: 0.7 ml•min-1; Injection volume: $10 \mu \mathrm{L}$; Column temperature: $25^{\circ} \mathrm{C}$; detection wavelength: $250 \mathrm{~nm}$ ).

\section{MECHANISM ANALYSIS}

If the expected result of this research has been obtained, the mechanism analysis of $E g \mathrm{P} 450$ and IFS (P450 from $P$. mirifica) will be performed using PROSITE (http://prosite. expasy.org/) and describing protein domains, functional sites as well as associated patterns and profiles to identify them.

\section{STATISTICAL ANALYSIS}

The contents of puerarin, genistein and daidzein among the 3 groups of $P$. mirifica were compared and the results were also expressed as the Mean \pm S.D. Data analysis was done base on analysis of variance (ANOVA) using R 2.50 version software (R Development Core Team. 2012) with Hmisc package (Harrell 2013). Significant level utilized in the data analysis was 0.05 .

\section{RESULTS}

\section{IDENTIFYING P. MIRIFICA SPECIES}

A total of 15 DNA sequences of White Kwao Krua has been obtained (supplement Table 2). Choosing one of each barcode sequences was performed with BLAST analysis (http://blast.ncbi.nlm.nih.gov/Blast.cgi). matK and ITS region DNA sequences of $P$. mirifica could be found in BLAST results. The pairwise distances between the sequences of $P$. mirifica in NCBI and the sequences which obtained in the research plants are not more than

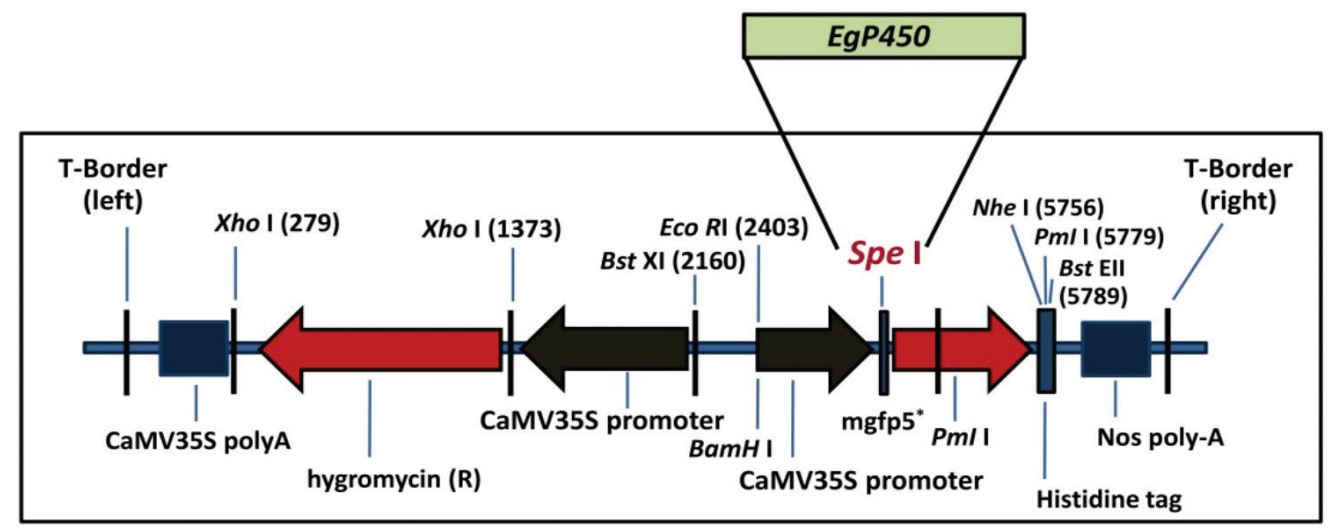

SUPPLEMENT FIGURE 1 . The diagram of pCAMBIA 1303-EgP450 
0.006 . However, $r b c L$ and $p s b A$-trnH of $P$. mirifica could not found in BLAST results. 12-21 DNA sequences in BLAST results were selected to construct phylogenetic trees by MEGA package.

\section{BOMBARDMENT AND IDENTIFICATION}

Our lab had obtained full-length EgP450 gene from the EST library and it had an open reading frame (ORF) of $1515 \mathrm{bp}$ encoding a protein of 505 amino acids (GenBank accession no. GU117705) (Phongdara et al. 2012). Three flowerpots of $P$. mirifica were bombarded for each experiment: T1-pCAMBIA 1303-EgP450 (T1), T2-Empty vector pCAMBIA 1303 (T2), and T3-Ggold particle control (T3). Six-weeks-old putative transgenic plants were examined directly for green fluorescence with a Confocal Laser Scanning microscope. T1 and T2 group plants showed several green fluorescence spots inside the cells, whereas fluorescence was not detected after the bombardment of the T3 group plants. Also, the insertion of recombinant DNA into the plant genome was verified in the survived transformed plants using a GFP primer and an $E g \mathrm{P} 450$ primer to amplify the three group plants. The 531-bp PCR products of $18 \mathrm{~S}$ primer found in all three group plants and 350-bp PCR products of GFP primer found in T1 and T2 group plants, 380-bp PCR products of $E g \mathrm{P} 450$ primer were found only in T1group plants. The PCR product of $E g \mathrm{P} 450$ primer was purified and sequenced. Only one sequence appeared after alignment sequence by BLAST in NCBI (GU117705.1). To summarize, EgP450 successfully transferred to T1 group plants.

\section{COMPARE THE ISOFLAVONOIDS}

Puerarin, genistein and daidzein of three group plants were determined by HPLC. The data were analyzed by analysis of variance (ANOVA). Genistein contents were statistically significant between T1 and T2 group plants $(p<0.01)$ and they were also statistically significant between $\mathrm{T} 1$ and $\mathrm{T} 3$ group plants $(p<0.05)$. Daidzein contents in the T1 group plants are statistical significant than other two groups $(p<0.05)$. Puerarin contents in three group trees show no significant differences $((\mathrm{F}=3.445, p>0.05)$.

\section{MECHANISM ANALYSIS}

BLASTX alignments of EgP450 protein, and then chose 4 similar sequences were from other species to compare using clustalX2. The EgP450 proteins contain the similar characteristic functional in the six species, such as oxygen binding site region, aromatic region and active site (red box). From the structure characteristics, EgP450 and $P$. mirifica $\mathrm{P} 450$ should present similar functions.

\section{DISCUSSION}

In our study, White Kwao Krua was bought from Lampang province of Thailand and identified by professional taxonomist; we further confirmed the species by DNA barcode technique. The $r b c L, p s b A-t r n H$, matK and ITS region sequence of White Kwao Krua were obtained in this research. The phylogenetic results of these sequences were constructed. In combination with the morphological characteristics of plants and other information, we can accurately identify that the White Kwao Krua which was bought from Lampang province were $P$. candollei var mirifica or P. mirifica.

In previous work, a clone homologous to $\mathrm{P} 450$ (namely $E g \mathrm{P} 450$ ) was selected from the list of highly expressed genes in our oil palm EST libraries (Phongdara et al. 2012). After an in-depth analysis, the $P 450$ protein of oil

SUPPLEMENT TABLE 2 . The length, percentage similarity of overlap section and GenBank accession of DNA fragments

\begin{tabular}{llcclll}
\hline \multirow{2}{*}{ DNA fragments } & & Length (bp) & $\begin{array}{c}\text { Pairwise } \\
\text { distances scot }\end{array}$ & Voucher number & $\begin{array}{c}\text { Gen Bank } \\
\text { accession }\end{array}$ & GI \\
\hline \multirow{2}{*}{ matK } & Sample 1 & 532 & -- & DLXY130517PM01 & KM982345 & 874527190 \\
& Sample 2 & 532 & -- & DLXY130517PM02 & KM982346 & 874527192 \\
& Sample 3 & 532 & -- & DLXY130517PM03 & KM982347 & 874527194 \\
18S & Sample 1 & 354 & -- & DLXY130517PM01 & KM982348 & 874527196 \\
& Sample 2 & 354 & -- & DLXY130517PM02 & KM982349 & 874527197 \\
& Sample 3 & 354 & -- & DLXY130517PM03 & KM982350 & 874527198 \\
ITS region & Sample 1 & 790 & 0.000 & DLXY130517PM01 & KM982351 & 874527199 \\
& Sample 2 & 790 & 0.000 & DLXY130517PM02 & KM982352 & 874527200 \\
& Sample 3 & 791 & 0.000 & DLXY130517PM03 & KM982353 & 874527201 \\
psbA-trnH & Sample 1 & 723 & -- & DLXY130517PM01 & KM982354 & 874527202 \\
& Sample 2 & 680 & -- & DLXY130517PM02 & KM982355 & 874527204 \\
& Sample 3 & 724 & -- & DLXY130517PM03 & KM982356 & 874527206 \\
rbcL & Sample 1 & 729 & $\leq 0.006$ & DLXY130517PM01 & KM982357 & 874527208 \\
& Sample 2 & 700 & $\leq 0.006$ & DLXY130517PM02 & KM982358 & 874527210 \\
& Sample 3 & 700 & $\leq 0.003$ & DLXY130517PM03 & KM982359 & 874527212 \\
\hline
\end{tabular}

The results of pairwise distances scot was respectively compared with P.mirifica in NCBI 
a

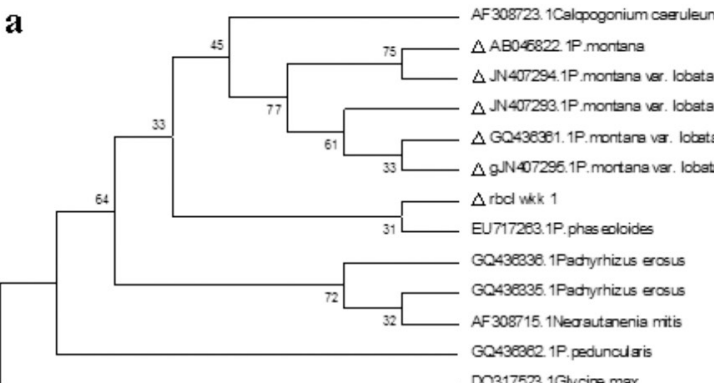

c

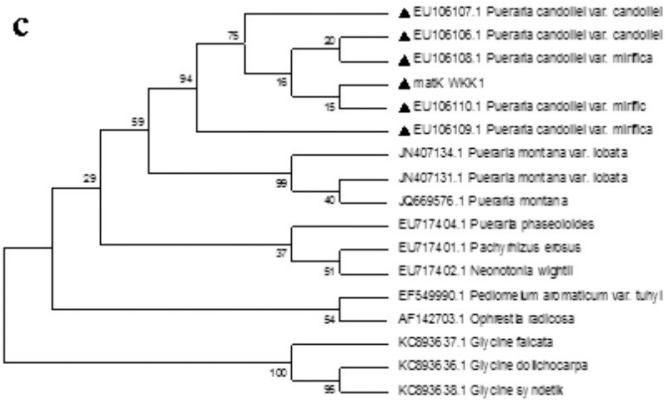

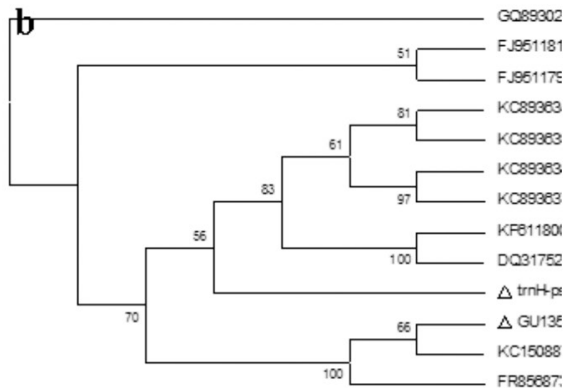

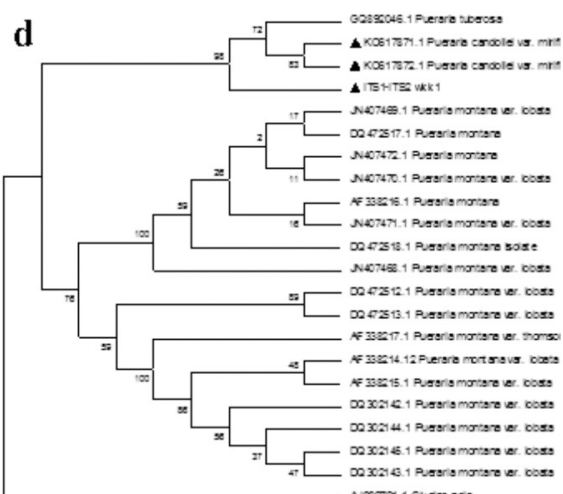

FIGURE 1. The phylogenetic trees analysis of four barcodes ( $\mathrm{a} ; \mathrm{rbcL}$, b; $p s b A-t r n H$, $\mathrm{c} ; m a t K$ and d; ITS region) of White Kwao Krua and other species were analyzed by maximum likelihood method and evolutionary analyses were conducted in MEGA6

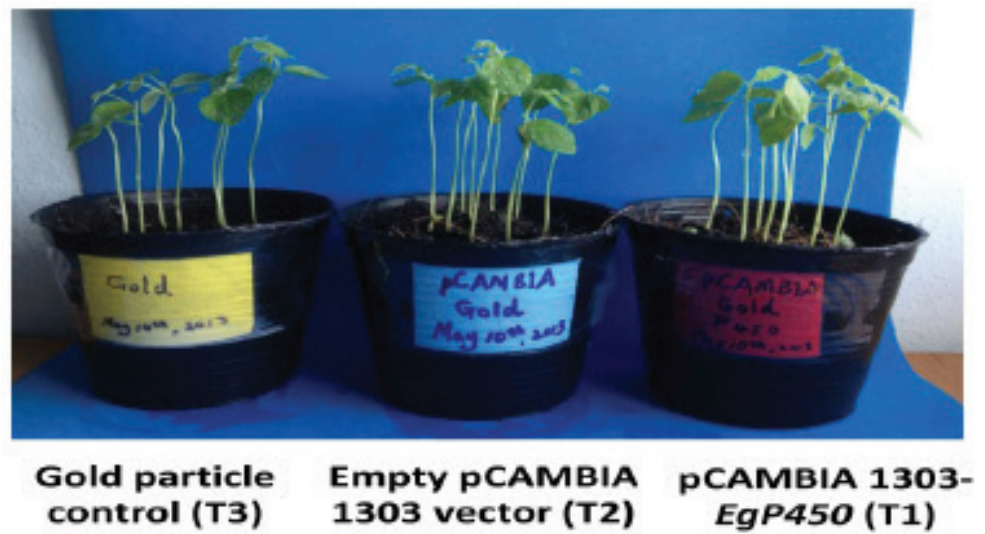

FIGURE 2. The putative transgenic of P. mirifica were cultivated in the small flowerpots containing soil until the sprouts hight reach five centimeters and were used for transformation. The three sets of flowerpots of $P$. mirifica were bombarded for each experiment with following DNA: pCAMBIA 1303-EgP450 (T1), empty pCAMBIA 1303 vector (T2) and gold particle control (T3)

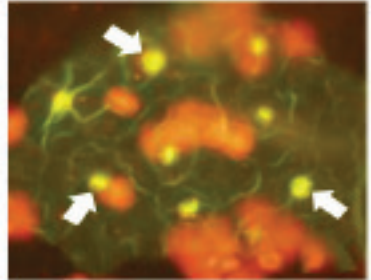

PCAMBIA 1303-EgP450 (T1)

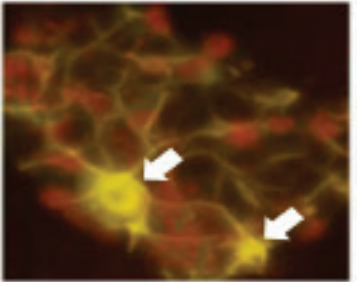

(T2)

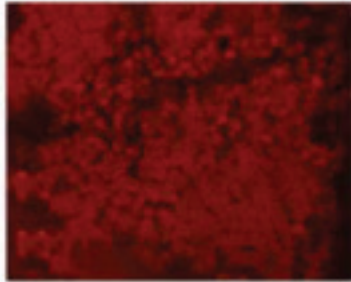

Gold particle control (T3)

FIGURE 3. Fluorescence microscope with cell sens standard software was chosen to identify the transgenic plants. Fluorescent light found in T1 plant (pCAMBIA 1303-EgP450) and T2 plant (-empty pCAMBIA 1303 vector) but visualization of GFP fluorescence not found inside the T3 plants $(1.0 \mu \mathrm{m}$ gold particle control) 


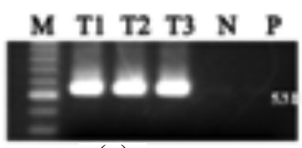

(a)

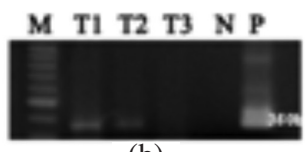

(b)

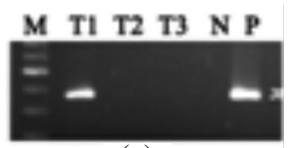

(c)

FIGURE 4. The PCR products presented the different fragments by specific primers, (a) showed 18S rDNA could be amplified in T1 plant (pCAMBIA 1303-EgP450), T2 plant (-empty pCAMBIA 1303 vector) and T3 plants (control gold particle); part (b) showed GFP could be amplified in T1, T2 plants and positive control; part (c) showed EgP450 could be amplified only in T1 plants and positive control (P), N-Negative control, M-100 bp DNA ladder

palm contains the same characteristic function domains as the CYP71 superfamily (Nelson et al. 1993). The sequence alignment demonstrates the closed relationships of $E g \mathrm{P} 450$ and $\mathrm{P} 450$ of protein from NCBI database. From the structure characteristics, EgP450, EgIFS and P. mirifica $\mathrm{P} 450$ should present similar domains of function.

IFS is one of the essential enzymes for engineering isoflavonoids production, because it is the entry point enzyme of biosynthesis. cDNAs encoding IFS have cloned from leguminous plants, and it has been transformed into Arabidopsis thaliana, tobacco and corn (Jung et al. 2000; Steele et al. 1999; Yu et al. 2000). Free genistein does not accumulate in Arabidopsis which express soybean IFS; then the isoflavone is converted to other compounds. The level of genistein conjugate production depends on the IFS activity level, substrate availability, substrate channeling and product turnover (Dixon \& Ferreira 2002).

To avoid risks of homology-dependent gene silencing (HDGS) (Meyer \& Saedler 1996), in this research EgP450 was chosen to transfer into $P$. mirifica, which directly cultivated in the flowerpots. The contents of isoflavonoids such as daidzein and genistein in transgenic P. mirifica, were higher than the control plants. There are some reasons about the mechanism. First, EgP450 and P. mirifica P450, which acting as Isoflavone synthase, should present similar functions in P. mirifica. The second, genetically modified donor plants from different classes may be able to avoid HDGS. The idea of choosing the synthetases from species of far genetic distance to create transgenic plants that were demonstrated here may provide a new way to obtain an excellent crop or herb in future works.

Daidzein of Pueraria mirifica has an anti-osteoporotic effect in postmenopausal women (Manonai et al. 2008). Genistein were used in both prophylaxis and treatment of diseases in recent years, acting such as antioxidant (Ganai \& Farooqi 2015; Kanazawa et al. 1995), anticancer properties (Sarkar \& Li 2002; Qi et al. 2011), cardioprotection (Deodato et al. 1999) and immunosupressor agent (Yellayi et al. 2002). Puerarin has been demonstrated to possess a variety of beneficial activities on alleviating angiocardiopathy (Pan et al. 2009), osteoporosis (Wong \& Rabie 2007) and hangover (Penetar et al. 2012). In the process of daidzein biosynthesis, the important step is that

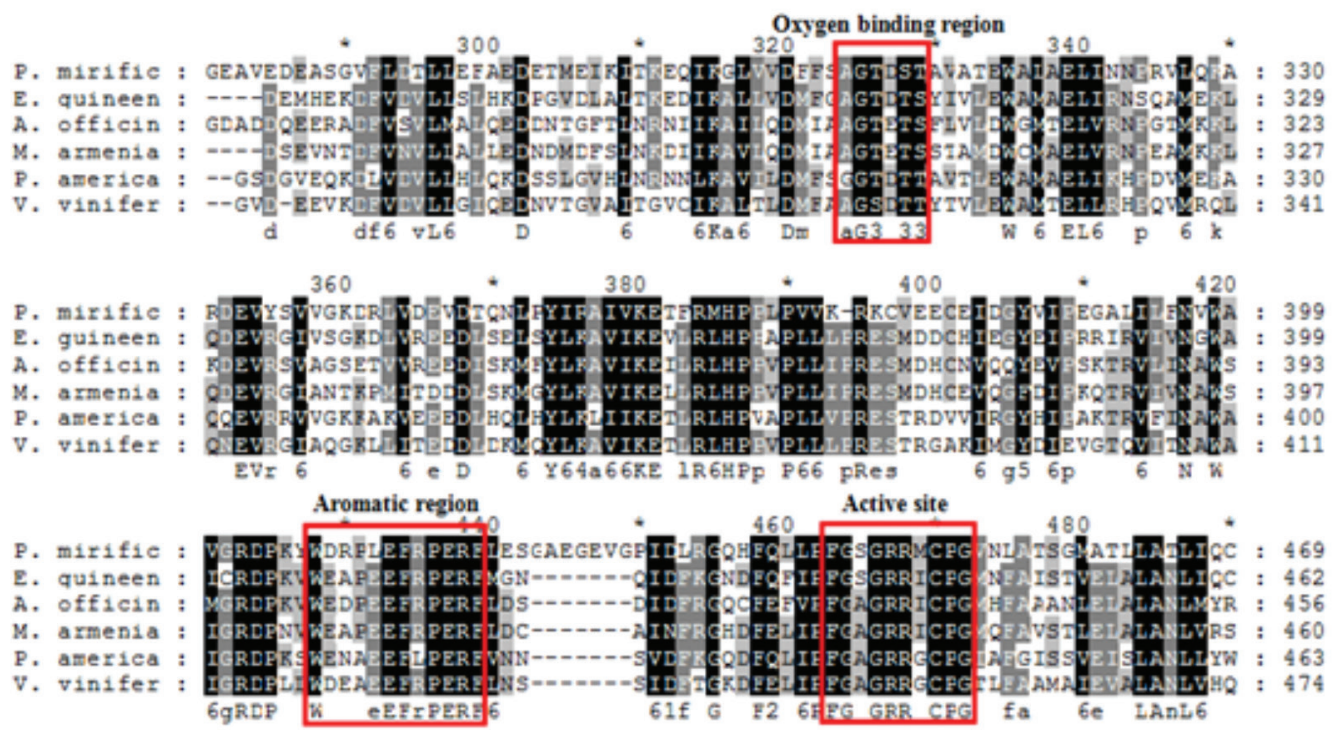

FIGURE 5. HPLC analysis of isoflavoniods that shows higher daidzein contents in T1 plant (pCAMBIA 1303-EgP450), T2 (-empty pCAMBIA 1303 vector) and T3 plants (gold particle control) $(p>0.05 ; *)$. It is also significant to compare among 3 groups in Genistein contents $(p>0.01 ; * *)$ 


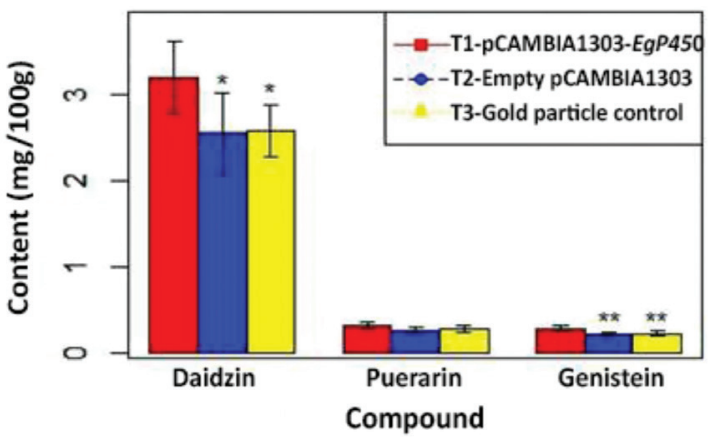

FIGURE 6. Multiple sequence alignment the P450 sequences of 6 species from P. mirifica (GenBank accession no. AFK64683), E. guineensis (GenBank accession no. ADM88550), A. officinalis (GenBank accession no. BAD06417),

M. armeniacum (GenBank accession no. BAD16679), P. americana (GenBank accession no. AAA32913) and $V$. vinifer (GenBank accession no.CAO64222). Conserved regions were highlighted in red boxes

trihydroxyisoflavanone is synthesized from liquirtigenin by IFS and then form daidzein and daidzein sequentially by HID and UGT. Genistein synthesized from naringenin by IFS and then forms genistin by UGT. The content of daidzein and genistein in transgenic plants of $P$. mirifica was higher than in the control plants. This phenomenon may be the cause from the EgP450 having similar functional domains with IFS. Although the content of Puerarin in some transgenic plants of $P$. mirifica was higher than the control plants, the total puerarin contents were not statistically significantly $(p>0.05)$ high. Further researches are required to engineer these synthesis pathways. This work is the first attempt to implement the use of transgenic $P$. mirifica to enhance the production of some targeted compounds of isoflavonoids.

\section{ACKNOWLEDGEMENTS}

This work was supported by the Center for Genomics and Bioinformatics Research and the government budget of Prince of Songkla University (SCI570197S). Scholarship to Mr. Li Xu was supported by the Graduated School, Prince of Songkla University, scholarship to Miss Ruethaithip Kaopong was supported by the National Research University Project of Thailand's Office of the Higher Education Commission (SCI540527M) and scholarship to Miss. Arthiya Chullasara was supported by the Research Assistant (RA) fund from the faculty of Science (1-255202-006)

\section{REFERENCES}

Bolwell, G.P., Bozak, K. \& Zimmerlin, A. 1994. Plant cytochrome P450. Phytochemistry 37(6): 1491-1506.

Cherdshewasart, W. \& Sriwatcharakul, S. 2007. Major isoflavonoid contents of the 1-year-cultivated phytoestrogenrich herb, Pueraria mirifica. Bioscience, Biotechnology, and Biochemistry Bioscience, Biotechnology, and Biochemistry 71(10): 2527-2533.

Cherdshewasart, W., Kitsamai, Y. \& Malaivijitnond, S. 2007a. Evaluation of the estrogenic activity of the wild Pueraria mirifica by vaginal cornification assay. The Journal of Reproduction and Development 53(2): 385-393.
Cherdshewasart, W., Subtang, S. \& Dahlan, W. 2007b. Major isoflavonoid contents of the phytoestrogen rich-herb Pueraria mirifica in comparison with Pueraria lobata. Journal of Pharmaceutical and Biomedical Analysis 43(2): 428-434.

Dhaubhadel, S. 2011. Regulation of isoflavonoid biosynthesis in soybean seeds. In Soybean - Biochemistry, Chemistry and Physiology, edited by Ng, T. Canada: InTech. pp. 243-258.

Deodato, B., Altavilla, D., Squadrito, G., Campo, G.M., Arlotta, M., Minutoli, L., Saitta, A., Cucinotta, D., Calapai, G., Caputi, A.P., Miano, M. \& Squadrito, F. 1999. Cardioprotection by the phytoestrogen genistein in experimental myocardial ischaemia-reperfusion injury. British Journal of Pharmacology 128(8): 1683-1690.

Dixon, R.A. \& Sumner, L.W. 2003. Legume natural products: Understanding and manipulating complex pathways for human and animal health. Plant Physiology 131(3): 878-885.

Dixon, R.A. \& Ferreira, D. 2002. Genistein. Phytochemistry 60(3): 205-211.

Felsenstein, J. 1985. Phylogenies and the comparative method. American Naturalist 125(1): 1-15.

Franzmayr, B.K., Rasmussen, S., Fraser, K.M. \& Jameson, P.E. 2012. Expression and functional characterization of a white clover isoflavone synthase in tobacco. Annals of Botany 110(6): 1291-1301.

Ganai, A.A. \& Farooqi, H. 2015. Bioactivity of genistein: A review of in vitro and in vivo studies. Biomedicine \& Pharmacotherapy 76: 30-38.

Harrell, F.J. 2013. RMS: Regression Modeling Strategies. R package version 3.6-3. http://cran.r-project.org/package=rms. Accessed on 1 July 2013.

Hashim, M.F., Hakamatsuka, T., Ebizuka, Y. \& Sankawa, U. 1990. Reaction mechamism of oxidative rearrangement of flavanone in isoflavone biosynthesis. FEBS Letters 271(1\&2): 219-222.

He, X., Blount, J.W., Ge, S., Tang, Y. \& Dixon, R.A. 2011. A genomic approach to isoflavone biosynthesis in kudzu (Pueraria lobata). Planta 233(4): 843-855.

Ingham, J.L., Tahara, S. \& Pope, G.S. 2002. Chemical components and pharmacology of the rejuvenating plant Pueraria mirifica. In Pueraria, edited by Keung, W.M. Boston: Taylor and Francis. pp. 97-118.

Ito, F., Iwasaki, M., Watanabe, T., Ishikawa, T. \& Higuchi, Y. 2005. The first total synthesis of kwakhurin, a characteristic component of a rejuvenating plant, "kwao keur": toward 
an efficient synthetic route to phytoestrogenic isoflavones. Organic \& Biomolecular Chemistry 3(4): 674-681.

Jung, W., Yu, O., Lau, S.C., O'Keefe, D.P., Odell, J., Fader, G. \& McGonigle, B. 2000. Identification and expression of isoflavone synthase, the key enzyme for biosynthesis of isoflavones in legumes. Nature Biotechnology 18(2): 208-212.

Kanazawa, T., Osanai, T., Zhang, X.S., Uemura, T., Yin, X.Z., Onodera, K., Oike, Y. \& Ohkubo, K. 1995. Protective effects of soy protein on the peroxidizability of lipoproteins in cerebrovascular diseases. Journal of Nutrition 125(3): 639S-646S.

Lakshnakara, M.C., Suvatabandhu, K. \& Airy Shaw, H.K. 1952. Kew Bulletin of Miscellaneous Information 7: 549-552.

Larkin, M.A., Blackshields, G., Brown, N.P., Chenna, R., McGettigan, P.A., McWilliam, H., Valentin, F., Wallace, I.M., Wilm, A., Lopez, R., Thompson, J.D., Gibson, T.J. \& Higgins, D.G. 2007. Clustal W and Clustal X version 2.0. Bioinformatics 23(21): 2947-2948.

Malaivijitnond, S., Kiatthaipipat, P., Cherdshewasart, W., Watanabe, G. \& Taya, K. 2004. Different effects of Pueraria mirifica, a herb containing phytoestrogens, on LH and FSH secretion in gonadectomized female and male rats. Journal of Pharmacological Sciences 96(4): 428-435.

Malaivijitnond, S. 2012. Medical applications of phytoestrogens from the Thai herb Pueraria mirifica. Frontiers of Medicine in China 6(1): 8-21.

Manonai, J., Chittacharoen, A., Udomsubpayakul, U., Theppisai, H. \& Theppisai, U. 2008. Effects and safety of Pueraria mirifica on lipid profiles and biochemical markers of bone turnover rates in healthy postmenopausal women. Menopause-the Journal of the North American Menopause Society 15(3): 530-535.

Meyer, P. \& Saedler, H. 1996. Homology-dependent gene silencing in plants. Annual Review of Plant Biology 47: 23-48.

Nakkaew, A., Chotigeat, W. \& Phongdara, A. 2010. Molecular cloning and expression of EgTCTP, encoding a calcium binding protein, enhances the growth of callus in oil palm (Elaeis guineensis, Jacq). Songklanakarin Journal of Science and Technology 32(6): 561-569.

Nelson, D.R., Kamataki, T., Waxman, D.J., Guengerich, F.P., Estabrook, R.W., Feyereisen, R., Gonzalez, F.J., Coon, M.J., Gunsalus, I.C. \& Gotoh, O. 1993. The P450 superfamily: Update on new sequences, gene mapping, accession numbers, early trivial names of enzymes, and nomenclature. DNA and Cell Biology 12(1): 1-51.

Pan, Z.Y., Bao, Z.S., Wu, Z.M., Wang, X.M., Zheng, J.Z., Shen, Y.L. \& Zhang, X.M. 2009. The myocardial protective effects of puerarin on STZ-induced diabetic rats. Journal of Molecular Cell Biology 42(2): 137-144.

Penetar, D.M., Toto, L.H., Farmer, S.L., Lee, D.Y., Ma, Z., Liu, Y. \& Lukas, S.E. 2012. The isoflavone puerarin reduces alcohol intake in heavy drinkers: A pilot study. Drug Alcohol Depend 126(1\&2): 251-256.

Phongdara, A., Nakkaew, A. \& Nualkaew, S. 2012. Isolation of the detoxification enzyme EgP450 from an oil palm EST library. Pharmaceutical Biology 50(1): 120-127.

Qi, W., Weber, C.R., Wasland, K. \& Savkovic, S.D. 2011. Genistein inhibits proliferation of colon cancer cells by attenuating a negative effect of epidermal growth factor on tumor suppressor FOXO3 activity. BMC Cancer 11: 219.

$\mathrm{R}$ Development Core Team. 2012. R: A Language and Environment for Statistical Computing. R Foundation for Statistical Computing, Vienna, Austria.
Sarkar, F.H. \& Li, Y. 2002. Mechanisms of cancer chemoprevention by soy isoflavone genistein. Cancer Metastasis Reviews 21(3\&4): 265-280

Sawada, Y., Kinoshita, K., Akashi, T., Aoki, T. \& Ayabe, S. 2002. Key amino acid residues required for aryl migration catalysed by the cytochrome P450 2-hydroxyisoflavanone synthase: For cell and molecular biology. The Plant Journal 31(5): 555-564.

Schuler, M.A. 1996. Plant cytochrome P450 monooxygenases. Critical Reviews in Plant Sciences 15(3): 235-284.

Sneath, P.H.A. \& Sokal, R.R. 1973. Numerical Taxonomy: In the Principles and Practice of Numerical Classification. San Francisco, California: W.H. Freeman and Company. pp. 230-234.

Steele, C.L., Gijzen, M., Qutob, D. \& Dixon, R.A. 1999. Molecular characterization of the enzyme catalyzing the aryl migration reaction of isoflavonoid biosynthesis in soybean. Archives of Biochemistry and Biophysics 367(1): 146-150.

Tamura, K., Nei, M. \& Kumar, S. 2004. Prospects for inferring very large phylogenies by using the neighbor-joining method. Proceedings of the National Academy of Sciences 101(30): 11030-11035.

Tamura, K., Stecher, G., Peterson, D., Filipski, A. \& Kumar, S. 2013. MEGA6: Molecular evolutionary genetics analysis version 6.0. Molecular Biology and Evolution 30(12): 2725-2729.

Tian, L. \& Dixon, R.A. 2006. Engineering isoflavone metabolism with an artificial bifunctional enzyme. Planta 224(3): 496507.

Urasopon, N., Hamadad, Y., Asaokae, K., Poungmalic, U. \& Malaivijitnond, S. 2008. Isoflavone content of rodent diets and its estrogenic effect on vaginal cornification in Pueraria mirifica treated rats. ScienceAsia 34: 371-376.

Wong, R. \& Rabie, B. 2007. Effect of puerarin on bone formation. OsteoArthritis and Cartilage 15(8): 894-899.

Yellayi, S., Naaz, A., Szewczykowski, M.A., Sato, T., Woods, J.A., Chang, J., Segre, M., Allred, C.D., Helferich, W.G. \& Cooke, P.S. 2002. The phytoestrogen genistein induces thymic and immune changes: A human health concern? Proceedings of the National Academy of Sciences 99(11): 7616-7621.

Yu, O., Jung, W., Shi, J., Croes, R.A., Fader, G.M., McGonigle, B. \& Odell, J.T. 2000. Production of the isoflavones genistein and daidzein in non-legume dicot and monocot tissues. Plant Physiology 124(2): 781-794.

Yusakul, G., Putalun, W., Udomsin, O., Juengwatanatrakul, T. \& Chaichantipyuth, C. 2011. Comparative analysis of the chemical constituents of two varieties of Pueraria candollei. Fitoterapia 82(2): 203-207.

Center for Genomics and Bioinformatics Research Department of Molecular Biotechnology and Bioinformatics Faculty of Science, Prince of Songkla University Hatyai, Songkhla 90112

Thailand

*Corresponding author; email: pamornra@yahoo.com

Received: 31 August 2016

Accepted: 17 April 2017 